\title{
Pengaruh Pelatihan Kerja Terhadap Kinerja Karyawan (Studi Kasus Pdam Tirta Bumi Wibawa Kota Sukabumi)
}

\author{
Oleh : \\ Apip Supriatna dan Mamun Sutisna \\ Politeknik Negeri Bandung
}

\begin{abstract}
The fact that human resources (employee) often dominant and play an active role in organization activities is the reason why this studi need to be done. Along with the development of science and knowledge more advanced then the companies are expected to be able to make its employees more skilled and trained in doing its job. One effort than can be done to improve the performance of the company's employess of such companies is to conduct employee training. This research uses the sampling method sampling with nonprobability saturated, while the techniques of data collection is done by doing a spread of questionnaires to the 110 respondents, The data analysis method in this research are test forassumptions of classical, analisa deskriftif, analisa korelasi,test hypothesis, analisa regresidan koefesien determination. The result obtained in this study that the training provided at PDAM Tirta Bumi Wibawa Kota Sukabumi to employees classified as good or high, performance in PDAM Tirta Bumi Wibawa Kota Sukabumi have good. Based on the research tha has been done, the regression equation is $Y+43.163+0.392 X$. results of the study stated that in PDAM Tirta Bumi Wibawa Kota Sukabumi job training and the performance of the employees have a positive relationship of 0.396 and training work affect the performance of the employees of $15.7 \%$ and $84,3 \%$ explained by other factors by the salary, work environment, organizational culture, leadership and motivasi
\end{abstract}

Keywords : Job training and employee performance

\section{Latar Belakang}

Keberhasilan suatu instansi/ organisasi tidak saja ditentukan oleh modal dan fasilitas yang dimiliki, tetapi juga tersedianya sumber daya manusia yang handal. Setiap organisasi membutuhkan sumber daya manusia yang sehat jasmani dan rohani, memiliki mental yang baik, disiplin, semangat, kemampuan serta keahlian yang sesuai dengan tantangan dan kebutuhan dunia kerja.

Salah satu penyebab turunnya kinerja karyawan dalam suatu organisasi, adalah dikarenakan adanya ketidaksesuaian antara tingkat kemampuan yang dimiliki oleh para karyawan, dengan perkembangan kebutuhan dan dinamika permasalahan yang dihadapi oleh dunia kerja yang semakin kompetitif. Banyak pihak yang berpendapat bahwa diantara faktorfaktor yang mempengaruhi penurunan kemampuan karyawan adalah kurangnya perharian instansi/organisasi dalam memberikan program pelatihan yang sesuai bagi karyawannya.

Sumarsono : (2004:273) berpendapat bahwa Perubahan-perubahan yang begitu cepat terjadi dalam pemerintahan Indonesia saat ini menurut kemampuan untuk mengadaptasi pada keterampilan-keterampilan baru dan kapabilitas semua karyawan di setiap tingkatan.Dengan adanya pelatihan ini diharapkan agar para karyawan dapat bekerja lebih efektif dan efesien. Berikut adalah data nilai kinerja karyawan PDAM Tirta Bumi Wibawa Kota Sukabumi pada Tahun 2013 sampai Tahun 2015. 
Tabel 1 Data Penilaian Kinerja Karyawan PDAM Trita Bumi Wibawa Tahun 2013-2015

Sumber : Sub Bagian Kepegawaian dan Hukum PDAM Tirta Bumi Wibawa

\begin{tabular}{|cccc|}
\hline Tahun & $\begin{array}{c}\text { Jumlah karyawan } \\
\text { yang ikut pelatihan }\end{array}$ & Nilai & $\begin{array}{c}\text { Naik } \\
\text { (Turun) }\end{array}$ \\
\hline $\mathbf{2 0 1 3}$ & 47 & 40.35 & - \\
\hline $\mathbf{2 0 1 4}$ & 53 & 47.25 & 6.90 \\
& & & \\
\hline $\mathbf{2 0 1 5}$ & 50 & 46.15 & -1.1 \\
& & & \\
\hline
\end{tabular}

Berdasarkan tabel 1.1 diatas bahwa terjadi penurunan kinerja karyawan. Data menunjukan bahwa pada tahun 2013 nilai kinerja karyawan menunjukan 40.35 dengan kategori "Kurang", pada tahun 2014 menunjukan angka 47.25 dengan kategori "Cukup" dan ditahun 2015 menunjukan angka 46.15 dengan kategori "Cukup". Penilaian tersebut meliputi beberapa aspek diantaranya : Aspek Administrasi. Aspek Keuangan, dan Aspek Operasional. Pada tahun 2015 mengalami penurunan sebesar 1,1 yang disebabkan oleh aspek operasional, yang hanya memberikan layanan air bersih rata-rata hanya selama 12 jam sehari namun dalam kenyataannya sering mengalami gangguan pada saluran air, yang mengakibatkan jumlah saluran air yang ditutup lebih tinggi dari pada jumlah sambungan baru, Dengan demikian, bisa dikatakan kinerja karyawan PDAM Tirta Bumi Wibawa Kota Sukabumi pada tahun 2015 belum optimal dan perlu ditingkatkan untuk mencapai kinerja perusahaan yang lebih baik lagi di masa yang akan datang.

Berdasarkan uraian fenomena tersebut, maka penulis tertarik untuk melakukan penelitian dengan judul "Pengaruh Pelatihan Kerja Terhadap Kinerja Karyawan PDAM Tirta Bumi Kota Sukabumi”"

\section{Perumusan Masalah}

Dari uraian latar belakang diatas maka permasalahan yang akan dianalisis adalah sebagai berikut :

1. Bagaimana pelaksanakaan pelatihan kerja karyawan di PDAM Tirta Bumi Wibawa Kota Sukabumi

2. Bagaimana kinerja karyawan PDAM Tirta Bumi Wibawa Kota Sukabumi

3. Bagaimana pengaruh program pelatihan kerja terhadap kinerja PDAM Tirta Bumi Wibawa Kota Sukabumi

\section{Hipotesis Penelitian}

Berdasarkan latar belakang masalah, tujuan penelitian dan tinjuan pustaka maka hipotesis yang dibuat sebagai berikut :

Ha: Terdapat pengaruh yang siginfikan antara pelatihan kerja dengan kinerja karyawan Ho: Tidak terdapat pengaruh yang siginifiksan antara pelatihan kerja dengan kinerja karyawan 


\section{Pelatihan}

Menurut pasal 1 ayat 9 Undang-undang No 13 Tahun 2003 pelatihan kerja adalah keseluruhan kegiatan untuk memberi, memperoleh, meningkatkan, serta mengembangkan kompotensi kerja, disiplin, sikap dan etos kerja pada tingkatan keterampilan dan keahlian tertentu sesuai dengan jenjang dan kualifikasi jabatan dan pekerjaan.

Menurut Handoko (2012 : 104) mendefiniskan bahwa"Latihan dimaksudkan untuk memperbaiki penguasaan berbagai keterampilan dan teknik pelaksanaan kerja tertentu, terperinci dan rutin.

Menurut Dessler (2011 :263) Pelatihan adalah proses mengajar keterampilan yang dibutuhkan karyawan baru untuk melakukan pekerjaannya .

Sedangkan menurut Sikula (dalam Mangkunegara 2012 : 50) mengatkan bahwa pelatihan adalah suatu proses pendidikan jangka pendek yang mempergunakan prosedur sistematis dan terorganisir dimana pegawai non managerial mempelajari pengetahuan dan keterampilan teknik dalam tujuan terbatas.

Gambar 2.1

\section{Bagan Metode Pelatihan}

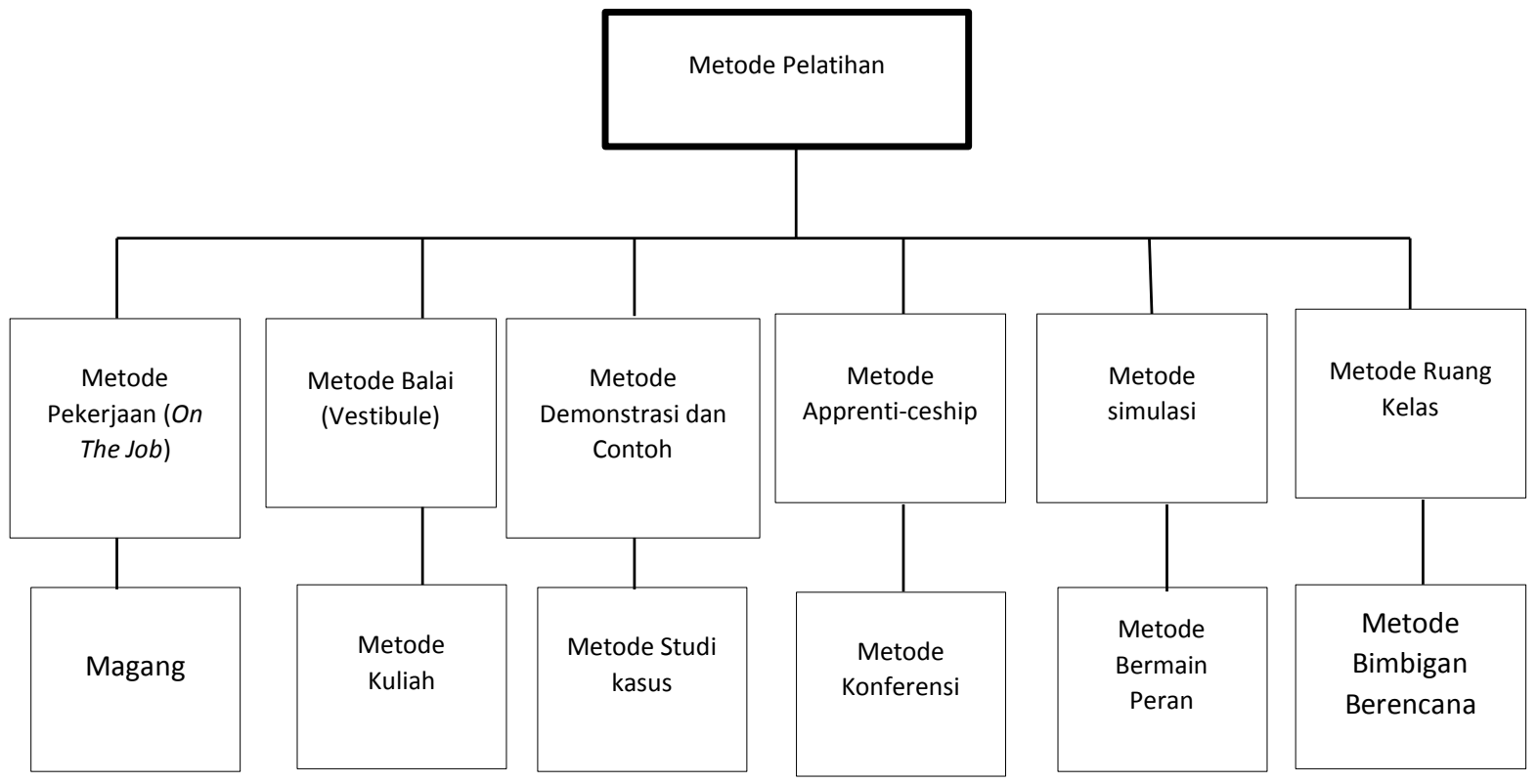

Sumber : DR. A.A. Anwar Prabu Mangkunegara (2006 : 67)

Menurut Kaswan (2011:199) Metode Pelatihan dapat dikelompokan dalam tiga cara : presentasi informasi, metode simulasi dan pelatihan On The Job Training (OJT).

\section{Evaluasi Hasil Program Pelatihan}

Menurut Kaswan (2012 : 237) menjelaskan bahwa evaluasi program pelatihan merupakan suatu cara mengumpulkan secara sistematis terhadap informasi deskriptif dan penilaian yang diperlukan untuk membantu keputusan pelatihan yang efektif yang terikat dengan seleksi, adopsi, nilai dan modifikasi aktifitas pembelajaran yang bervariasi 
Gambar 2.2

Langkah-langkah Evaluasi Pelatihan

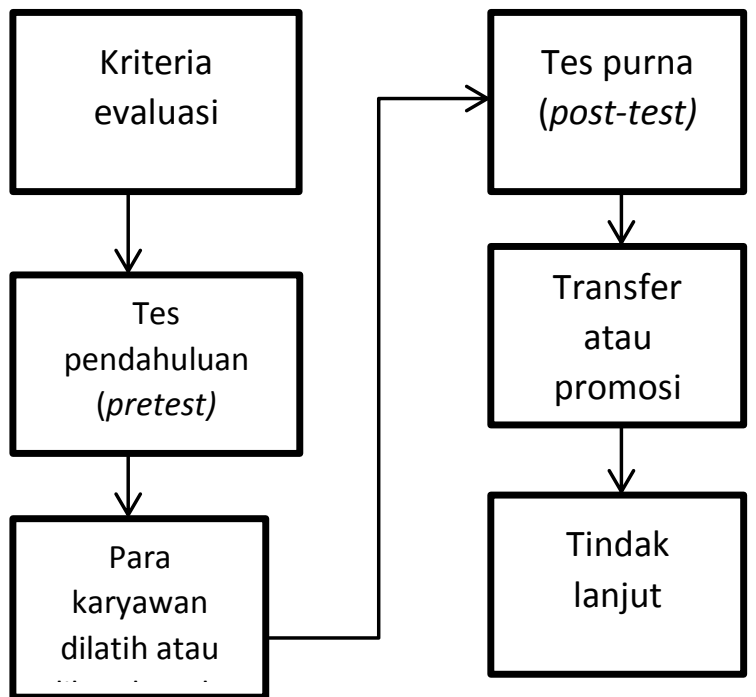

Sumber : Handoko $(2012: 120)$

\section{Kinerja}

Menurut Wibowo (2011 : 23), Kinerja berasal dari pengertian Performance, ada pula yang memberikan pengertian Performance sebagai hasil kerja atau prestasi kerja,

Menurut Mangkunegara (dalam Yulianti 2015 :904) menjelaskan bahwa, kinerja adalah hasil kerja secara secara kualitas dan kuantitas yang dicapai oleh seorang karyawan dalam melaksanakan tugasnya sesuai dengan tanggung jawab yang diberikan.

Sedangkan menurut Roziqin (2010:42) kinerja secara umum dapat diartikan sebagai keseluruhan proses bekerja dari individu yang hasilnya dapat digunakan landasan untuk menentukan apakah pekerjaan individu tersebut baik atau sebaiknya.

\section{Faktor - faktor yang mempengaruhi Kinerja Karyawan}

Menurut Mangkunegara (2012 : 14) mengatkan bahwa kinerja pada umumnya dipengaruhi oleh tiga faktor yaitu :

a. Faktor individual yang terdiri dari :

1 Kemampuan dan keahlian

2 Latar belakang

3 Demografi

b. Faktor psikologi yang terdiri dari :

1 Persepsi

2 Atitude

3 Personality

4 Pelatihan

5 Motivasi

c. Faktor organisasi yang terdiri dari :
1 Sumber daya
2 Kepemimpinan
3 Penghargaan
4 Struktur
5 Job Design 


\section{Penilaian Kinerja}

Menurut pengukuran atau penilaian kinerja (performance measurement) mempunyai pengertian suatu proses penilaian tentang suatu kemajuan pekerjaan terhadap tujuan dan sasaran dalam pengelolaan sumber daya manusia untuk menghasilkan barang dan jasa termasuk informas atas efesiensi serta efektifitas tindakan dalam mencapai tujuan organisasi.

Sedangkan menurut George dan Jones menyatakan bahwa ada tiga kriteria dalam melakukan penilaian kinerja individu yaitu :

a. Tugas individu

b. Perilaku individu, dan

c. Ciri individu

\section{Kerangka Pemikiran}

Sumber daya manusia merupakan elemen utama organisasi dibandingkan dengan elemen lain seperti modal, teknologi dan uang sebab manusia itu sendiri yang mengendalikan yang lain. Sumber daya manusia (SDM) tidak terlepas dari kegiatan-kegiatan atau proses manajemen lainnya seperti strategi perencanaan, pengembangan manajemen dan pengembangan organisasi. Keterkaitan antara aspek-aspek manajemen itu sangat erat sekali sehingga sulit bagi kita untuk menghindari dari pembicaraan secara terpisah satu dengan lainnya.

Hubungan pelatihan kerja terhadap kinerja karyawan juga dijelaskan oleh Hasibuan (2012 : 69) pengembangan karyawan melalui pendidikan dan pelatihan adalah usaha untuk meningkatkan kemampuan teknis, teoritis, konseptual, dan moral karyawan supaya kinerjanya baik dan mencapai hasil yang optimal,

Berdasarkan pola pikir yang telah diuraikan, maka dalam penelitian ini menempatkan Pelatihan kerja sebagai variabel independen yang mempengaruhi dan kinerja karyawan sebagai variabel dependen yang dipengaruhi. dari hasil tinjauan pustaka dan penelitian ini digambarkan dalam model penelitian sebagai berikut :

\begin{tabular}{|c|c|}
\hline Pelatihan Kerja (X) & Kinerja karyawan (X) \\
\hline a Kebutuhan pelatihan & Ketepatan hasil kerja \\
\hline b Tujuan pelatihan & b Ketelitian hasil kerja \\
\hline c Materi pelatihan & c Kehadiran \\
\hline d Metode pelatihan & d Peraturan perusahaan \\
\hline e Evaluasi & e Bekerjsama \\
\hline & f Peran serta \\
\hline
\end{tabular}

Gambar : 2.1 Paradigma Penelitian

\section{Tempat dan waktu penelitian}

Penelitian ini dilakukan di PDAM Tirta Bumi Wibawa Kota Sukabumi yang beralamat Jln Bhayangkara No 207 Sukabumi waktu pelaksanaan dimulai dari tanggal 21 maret 2016 s.d 21 juni 2016

\section{Metode penelitian}

Jenis penelitian ini adalah penelitian Explanatory, menurut Zulganef (2008 : 11), penelitian explanatory adalah penelitian yang bertujuan menelaah antar variabel yang menjelaskan suatu fenomena tertentu. Kemudian sesuai dengan maksud dan tujuan penelitian maka metode penelitian yang digunakan adalah deskriptif dan verifikasi. 
Pengertian metode deskriptif itu sendiri menurut Sugiyono (2012 :86), menjelaskan bahwa penelitian deskriptif adalah penelitian yang dilakukan untuk mengetahui nilai variabel mandiri, baik satu variabel atau lebih (independen) tanpa membuat perbandingan atau menghubungkan antara satu dengan variabel lain.

Metode verifikasi menurut Sugiyono (2013 : 19) adalah metode penelitian yang bertujuan mengetahui hubungan kualitas antar variabel melalui suatu pengujian hipotesis dengan suatu perhitungan statistic sehingga didapat hasil pembuktian yang menunjukan hipotesis ditolak atau diterima. Metode penelitian verifikasi ini bertujuan untuk menjawab permasalahan mengenai hubungan pelatihan karyawan dependen.

Sugiyono (2012 : 61) mengungkapkan pengertian populasi adalah wilayah generalisasi yang terdiri atas obyek/subyek yang mempunyai kualitas dan karakteristik tertentu yang ditetapkan oleh peneliti untuk dipelajari dan kemudian ditarik kesimpulannya sedangkan menurut Arikunto (2010 : 173) populasi adalah keseluruhan subjek penelitian.

Berdasarkan pengertian diatas dapat diambil kesimpulan bahwa populasi merupakan objek atau subyek berada pada wilayah dan memenuhi syarat tertentu yang berkaitan dengan masalah dalam penelitian. Populasi dalam penelitian ini adalah PDAM Tirta Bumi Wibawa Kota Sukabumi yang berjumlah 110 karyawan dan pemilihan populasi ini dirasakan cukup mewakili untuk memberi data yang diperlukan dalam penelitian.

Sampel yang digunakan dalam penelitian ini didapat dengan teknik pengambilan sampel (teknik sampling) Nonprobability sampling dengan Sampling jenuh. Pengertian Sampling jenuh menurut Sugiyono (2012 : 96) adalah teknik penentuan sampel apabila semua anggota populasi digunakan sebagai sampel.

Berdasarkan teknik pengambilan sampel di atas dengan menggunakan teknik sampling jenuh dari jumlah populasi sebanyak 110, maka yang diambil sebagai sampel adalah sebanyak 110 orang.

Dalam penelitian ini kuesioner didesain dengan menggunakan skala Likert. Dengan menggunakan skala Likert, maka variabel yang akan diukur dijabarkan menjadi indikator variabel. Kemudian indikator tersebut dijadikan sebagai titik tolak untuk menyusun item-item instrument yang berupa pernyataan (Sugiyono 2013)

Dalam pengukurannya, setiap responden diminta pendapatnya mengenai suatu pernyataan, dengan skala Likert penilaian dari 1 (satu) sampai dengan 5 (lima). Tanggapan positif atau sangat setuju (maksimal) diberi nilai paling besar (5) dan tanggapan negative atau sangat tidak setuju (minimal) diberi nilai paling kecil (1), sebagai berikut:

\section{Identitas Responden}

Data demografi responden terdiri dari jenis kelamin, usia, pendidikan dan masa kerja yang dapat dilihat pada tabel 2 .

Tabel 2 Identitas Responden

\begin{tabular}{|c|c|c|c|}
\hline No & \multicolumn{2}{|c|}{ Jenis Demografi } & Persentase \\
\hline \multirow{2}{*}{1} & \multirow{2}{*}{ Jenis kelamin } & Pria & $40 \%$ \\
\hline & & Wanita & $60 \%$ \\
\hline \multirow{3}{*}{2} & \multirow{3}{*}{ Usia } & $\leq 30$ Tahun & $17 \%$ \\
\hline & & 30 - 35 Tahun & $22 \%$ \\
\hline & & $35-40$ Tahun & $27 \%$ \\
\hline
\end{tabular}




\begin{tabular}{|c|c|c|c|}
\hline & & $\geq 40$ Tahun & $34 \%$ \\
\hline \multirow{3}{*}{3} & \multirow{3}{*}{$\begin{array}{c}\text { Pendidikan } \\
\text { Terakhir }\end{array}$} & SLTA & $20 \%$ \\
\hline & & Sarjana D4/S1 & $69 \%$ \\
\hline & & Diploma & $31 \%$ \\
\hline \multirow{4}{*}{4} & \multirow{4}{*}{ Masa Kerja } & 1-5 Tahun & $30 \%$ \\
\hline & & 5 -10 Tahun & $26 \%$ \\
\hline & & $10-15$ Tahun & $19 \%$ \\
\hline & & $\geq 15$ Tahun & $25 \%$ \\
\hline
\end{tabular}

Sumber : Olah Data (2016)

\section{Pelatihan Kerja PDAM Tirta Bumi Wibawa Kota Sukabumi}

Analisis deskriptif Pelatihan Kerja digunakan untuk menjawab rumusan masalah pertama yaitu bagaiaman pelatihan kerja di PDAM Tirta Bumi Wibawa Kota Sukabumi. Berdasarkan hasil olah data, diperoleh bahwa pelatihan kerja di PDAM Tirta Bumi Wibawa Kota Sukabumi berada pada tingkatan yang baik. Hasil tersebut berdasarkan perolehan nilai rata-rata sebesar 4.13 dengan standar deviasi 0,554 atau sama dengan 13,41\% dari mean. Merujuk pada BAB III tabel 3.7 angka 4,13 untuk mean berada pada skala interval 3,41-4,2 yang berarti bahwa pelatihan di PDAM Tirta Bumi Wibawa Kota Sukabumi Baik, dan jawaban responden dalam standar deviasi baik. Dimensi pelatihan kerja diantaranya adalah dimensi kebutuhan pelatihan, dimensi tujuan pelatihan, dimensi materi pelatihan, dimensi metode pelatihan, dimensi evaluasi pelatihan. Dari lima dimensi yang menentukan pelatihan kerja, dimensi tujuan pelatihan dan dimensi materi pelatihan dengan nilai mean terendah yaitu sebesar 4,06. Sedangkan dimensi dengan nilai mean tertinggi adalah dimensi kebutuhan pelatihan, yaitu sebesar 4,19.

Dimensi materi pelatihan memperoleh nilai rata - rata sebesar 4,06 dengan standar deviasi 0,701 atau $17,26 \%$ dari nilai mean.Merujuk pada tabel 3.7 maka nilai rata-rata tersebut berada pada interval 3,41 - 4,2 yang artinya materi pelatihan yang diberikan kepada karyawan PDAM Tirta Bumi Wibawa Kota Sukabumi memandang bahwa pelatihan dalam pelaksanaanya sudah menggunakan analisis kebutuhan pelatihan dengan baik sehingga, perusahaan dapat memberikan pelatihan sesuai dengan kebutuhan karyawannya. Mengacu pada teori analisis kebutuhan pelatihan dilakukan untuk meningkatkan kinerja atau menutupi kinerja yang tidak memenuhi standar bahwa analisis kebutuhan pelatihan adalah suatu diagnose untuk menentukan masalah yang dihadapi saat ini dan tantangan dimasa mendatang yang harus dipenuhi dalam program pelatihan

Dimensi Tujuan Pelatihan memperoleh nilai rata-rata 4,13 dengan standar deviasi 0,682 atau $16,51 \%$ dari nilai mean, nilai rata-rata tersebut berada pada interval $3,41-4,2$ yang artinya tujuan pelatihan yang di adakan di PDAM Tirta Bumi Wibawa Kota Sukabumi baik. Mengacu pada teori Mangkunegara (2006 : 52) tujuan pelatihan adalah meningkatkan penghayatan jiwa dan ideology, meningkatkan produktivitas kerja, meningkatkan kualitas kerja, meningkatkan sikap moral dan semangat kerja dan meningkatkan rangsangan agar pegawai mampu berprestasi secara maksimal.

Dimensi materi pelatihan memperoleh nilai rata - rata nilai rata-rata 4,13 dengan standar deviasi 0,682 atau $16,51 \%$ dari nilai mean, nilai rata-rata tersebut berada pada interval 3,41 - 4,2 yang artinya tujuan pelatihan yang di adakan di PDAM Tirta Bumi Wibawa Kota Sukabumi baik. Mengacu pada teori Mangkunegara (2012 : 52) tujuan pelatihan adalah 
meningkatkan penghayatan jiwa dan ideology, meningkatkan produktivitas kerja, meningkatkan kualitas kerja, meningkatkan sikap moral dan semangat kerja dan meningkatkan rangsangan agar pegawai mampu berprestasi secara maksimal.

Dimensi metode pelatihan memperoleh nilai rata - rata 4,14 dengan standar deviasi 0,599 atau $14,46 \%$ dari nilai mean. Nilai rata-rata tersebut berada pada interval 3,41-4,2 yang mempunyai arti bahwa karyawan PDAM Tirta Bumi Wibawa Kota Sukabumi memandang bahwa metode pelatihan yang diberikan dalam pelaksanaannya sudah baik. Berdasarkan hasil analisis dimensi metode pelatihan indikator yang paling rendah adalah reaksi terhadap metode pelatihan yang diberikan dengan nilai rata-rata mean 4.10 di bawah nilai mean dimensi. Mengacu pada teori Kaswan (2011 : 199) metode pelatihan dapat dikelompokan dalam tiga cara yaitu presentasi informasi, metode simulasi dan pelatihan on the job training (OJT).

Dimensi evaluasi pelatihan memperoleh nilai rata - rata 4,14 dengan standar deviasi 0,527 atau $12,7 \%$ dari nilai mean. Nilai rata-rata tersebut berada pada interval 3,41-4,2 yang mempunyai arti bahwa karyawan PDAM Tirta Bumi Wibawa Kota Sukabumi memandang bahwa evaluasi pelatihan dalam pelaksanaannya sudah baik. Pada dimensi ini jawaban terendah adalah 2 (dua) dan jawaban tertinggi 5 (lima), yang berarti bahwa masih ada beberapa karyawan yang tidak setuju dengan pernyataan dari tiap indikator, indikator dengan nilai mean terendah adalah sesuai dengan kebutuhan karyawan indikator ini memiliki nilai rata-rata mean 4,05 di bawah mean dimensi. Menurut teori Handoko (2012 : 19) pengertian evaluasi program pelatihan adalah implementasi program pelatihan berfungsi sebagai transformasi. Para karyawan yang tidak terlatih diubah menjadi karyawan-karyawan yang berkemampuan, sehingga dapat diberikan tanggung jawab lebih besar.

\section{Kinerja Karyawan PDAM Tirta Bumi Wibawa Kota Sukabumi}

Analisis deskriptif ini digunakan untuk menjawab identifikasi masalah yang kedua, yaitu bagaimana Kinerja karyawan di PDAM Tirta Bumi Wibawa Kota Sukabumi. Berdasarkan perhitungan dengan bantuan software SPSS, diperoleh hasil bahwa kinerja karyawan dapat dikatakan baik. Hal ini dapat dilihat dari mean yang menunjukan angka sebesar 4,18 yang artinya bahwa rata-rata dari jawaban responden 4,18. Merujuk pada tabel interpretasi rata-rata deskriftif pada bab 3 tabel 3.7, jika rata-rata 4,18 berada pada interval 3,41-4,2 yang berarti bahwa kinerja karyawan di PDAM Tirta Bumi Wibawa Kota Sukabumi Baik, dan jawaban responden dalam standar deviasi baik. Kemudian standar deviasi menunjukan angka 0,432 atau sama dengan $10,33 \%$ dari nilai mean, berarti jawaban responden terdapat pelatihan karyawan variatifnya sangat kecil, dapat dikatakan jawaban yang diberikan hampir sama karena berada di bawah $20 \%$.

Secara keseluruhan, data responden menunjukan bahwa kinerja karyawan di PDAM Tirta Bumi Wibawa Kota Sukabumi baik. Kinerja tersebut dapat dilihat berdasarkan 6 dimensi yang digunkan dalam penelitian variabel Kinerja Karyawan. Dimensi - dimensi tersebut adalah ketepatan hasil kerja, ketelitian hasil kerja, kehadiran, peraturan perusahaan, bekerjasama dan peran serta. Dimensi variabel kinerja karyawan dengan rata-rata tertingi adalah dimensi ketepatan hasil kerja yaitu 4,39 dengan standar deviasi 0,458, sedangkan dengan rata-rata terkecil berada pada dimensi peran serta yaitu 3,98 dengan standar deviasi 0,603 .

Dimensi ketepatan hasil kerja memperoleh nilai rata - rata sebesar 4,39 dengan standar deviasi 0,458 atau $10,43 \%$ dari nilai mean. Nilai rata-rata tersebut berada pada interval 4,21 - 5,0 yang berarti bahwa karyawan PDAM Tirta Bumi Wibawa Kota Sukabumi dalam melaksankan pekerjaan selalu tepat waktu dalam meyelesaikan pekerjaan selalu sesuai dengan target yang di tentukan oleh atasannya. Adapun indikator yang paling rendah dalam 
dimensi ini adalah jumlah kerja dengan nilai rata-rata mean 4.29 di bawah nilai rata-rata mean dimensi.

Karyawan PDAM tirta Bumi Wibawa Kota Sukabumi didominasi oleh tingkat pendidikan Sarjana S1/D4 yaitu sebanyak 54 orang dan karyawan yang pendidikan terakhirnya Diploma sebanyak 34 orang sedangkan untuk pendidikan terakhir SLTA sebanyak 22 orang. Menurut Novliadi (dalam Wardani , 2014 : 3) Diakatan bahwa mereka yang mempunyai tingkat pendidikan tidak terlalu tinggi akan memandang tugas-tugas yang sulit sebagai tekanan dan sumber kecamasan.

Dimensi ketelitian hasil kerja memperoleh nilai rata - rata 4,32 dengan standar deviasi 0,553 atau $12,80 \%$ dari nilai mean. Nilai rata-rata tersebut berdasarkan interval berada pada skala 4,21 - 5,0 yang berarti bahwa karyawan PDAM Tirta Bumi WIbawa Kota dinilai mempunyai ketelitian hasil kerja yang tinggi untuk menyelesaikan pekerjaan. Berdasarkan tabel 4.11 terdapat indikator yang paling rendah adalah indikator tingkat kesalahan bekerja dengan niai rata - rata mean 4.30 di bawah nilai mean dimensi. Dapat dilihat dari karakteristik responden berdasarkan usia karyawan yang berumur $40 \geq$ berjumlah 38 orang dan responden yang berumur dibawah 40 tahun berjumlah 72 orang. Karyawan usia dibawah 40 tahun cenderung memiliki tingkat kesalahan bekerja yang tinggi dikarenakan kurangnya pengalaman dalam bekerja. Kualitas kerja (output) diukur dari persepsi pegawai terhadap kualitas pekerjaan yang dihasilkan serta kesempurnaan tugas terhadap keterampilan dan kemampuan pegawai.

Dimensi kehadiran memperoleh nilai rata - rata 4,14 dengan standar deviasi 0,562 atau $13,57 \%$ dari nilai mean. Nilai rata-rata tersebut berada pada skala interval 3,41-4,2 yang mempunyai arti bahwa karyawan PDAM Tirta Bumi dinilai mempunyai tingkat kehadiran karyawan yang tinggi dalam bekerja. Berdasarkan tabel 4.12 diketahui bahwa indikator kemandirian memiliki nilai mean diatas nilai mean deimensi hal ini berarti intensitas karyawan dalam melakukan pekerjaan tergolong tinggi. Kehadiran ditempat kerja ialah pegawai yang memiliki kinerja tinggi, maka tingkat ketidaksesuainnya cenderung rendah.

Dimensi peraturan perusahaan memperoleh nilai rata-rata 4,20 dengan standar deviasi 0,543 atau $12,92 \%$ dari nilai mean. Nilai rata-rata tersebut berada pada skala interval 3,41 4,2 yang mempunyai arti bahwa karyawan PDAM Tirta Bumi Wibawa diniai mempunyai kedisiplinan yang tinggi dalam mentaati peraturan perusahaan. Mengacu pada peraturan daerah Kota Sukabumi Nomor 3 Tahun 2009 Tentang Perusahaan Daerah Air Minum Tirta Bumi Wibawa menimbang bahwa dalam rangka meningkatkan pelayanan dan kinerja serta dalam upaya menggali dan mengembangkan salah satu potensi bumi dan air untuk kemakmuran rakyat.

Dimensi bekerjasama nilai rata-rata 4,20 dengan standandar deviasi 0,531 atau $12,64 \%$ dari nilai mean. Nilai rata-rata tersebut berada pada skala interval 3,41-4,2 yang mempunyai arti bahwa karyawan PDAM Tirta Bumi Wibawa Kota Sukabumi dinilia tingkat bekerjasama yang tinggi dalam melakukan pekerjaannya. Mengacu pada teori Siagian (2012 : 78) kerjasama yaiutu kemampuan menangani hubungan dalam pekerjaan selain mendominasi kriteria tersebut, juga menunjuk performance atau kinerja dihasilkan oleh adanya tiga hal yaitu : kemampuan ayau ability dalam wujudnya sebagai kapasitas untuk berprestasi (capacity to performi), kemauan, semangat, hasrat atau motivasi dalam wujudnya sebagai kesediaan untuk berprestasi (willingness to perfrom), kesempatan untuk berprestasi (opertunity to perform).

Dimensi Peran Serta memperoleh nilai rata-rata 3,98 dengan standar deviasi 0,603 atau $15,15 \%$ dari nilai mean. Nilai rata-rata tersebut berada pada skala interval 3,42-4,2 yang mempunyai arti bahwa karyawan PDAM Tirta Bumi Wibawa Kota Sukabumi dinilai mempunyai peran serta yang tinggi. Mengacu pada teori Hasibuan (2012 : 105) peranan 
karyawan bagi sebuah perusahaan berupa keterlibatan mereka dalam sebuah perancanaa, sistem dan tujuan yang ingin dicapai oleh perusahaan.

\section{Pengaruh Pelatihan Kerja Terhadap Kinerja Karyawan}

Pembahasan pengaruh pelatihan kerja terhadap kinerja karyawan merupakan pembahasan yang akan menjawab perumusan masalah yang ketiga, yaitu bagaimana pengaruh pelatihan kerja terhadap kinerja karyawan PDAM Tirta Bumi Wibawa Kota Sukabumi.

Hasil pengujian yang dilakukan dalam penelitian ini terdapat variabel pelatihan dan kinerja karyawan menunjukan bahwa pelatihan memiliki hubungan yang signifikan dan positif terhadap kinerja karyawan yang ditunjukan oleh nilai person correlation sebesar $(+)$ 0,396 dan R Square sebesar 0,194. Dilihat dari R Square yang memberi petunjuk bahwa sebesar $14,9 \%$ dari variabel kinerja karyawan yang dapat di jelaskan oleh variabel pelatihan kerja.

Pelatihan kerja memiliki pengaruh terhadap kinerja karyawan. Hal ini berdasarkan hasil regresi sederhana dengan konstanta $(\alpha)$ bernilai 43,163 dengan koefesien regresi (b) 0,392 sehingga muncul persamaan regresi sebagai berikut $\mathrm{Y}=43,163+0,392 \mathrm{X}$. Dari persamaan regresi tersebut, dapat diketahui bahwa setiap penambahan satu angka pelatihan dengan koeesien regresi bernilai positif, maka kinerja karyawan akan meningkat sebesar 0,392. Sedangkan apabila pelatihan kerja sama dengan nol atau tidak ada perubahan, maka nilai kinerja karyawan sebesar 43,163 .

Pada penelitian ini ditemukan bahwa pelatihan memiliki hubungan secara signifikan dan positif terhadap faktor-faktor yang mempengaruhi kinerja karyawan yaitu sebesar $15,7 \%$ sedangkan sisanya 84,3\% dipengaruhi oleh faktor-faktor lain. Menurut Siagian (2010:12) faktor lain yang mempengaruhi kinerja karyawan yaitu dipengaruhi oleh gaji, lingkungan kerja, budaya organisasi, kepemimpinan dan motvasi.

Pelatihan kerja memiliki pengaruh yang signifikan terhadap kinerja karyawan. Hal ini sesuai dengan pengujian hipotesis dengan uji statistik $\mathrm{F}$ dan uji statistik $\mathrm{t}$. dalam pengujian statistik F interprestasi pengambian keputusan menurut Sugiyono (2012 : 368) adalah jika $F_{0}$ $\geq \mathrm{F}_{\mathrm{t}}$ dan $\mathrm{p} \leq 0,05$, maka $\mathrm{H}_{0}$ ditolak dan $\mathrm{H}_{\mathrm{a}}$ diterima. Pada hasil uji pengujian statistik $\mathrm{F}$, diperoleh $F$ hitung $\left(F_{0}\right)$ Sebesar 20,102 dan nilai untuk $F$ tabel $\left(F_{t}\right)$ yaitu 3,93 dengan nilai signifikan adalah 0,000 . Yang berarti nilai $F_{o} \geq F_{t}$ yaitu sebesar $20,102 \geq 3,93$. Sehingga dapat disimpulkan bahwa $\mathrm{H}_{\mathrm{o}}$ ditolak dan $\mathrm{H}_{\mathrm{a}}$ diterima, yang artinya terdapat pengaruh yang positif dan signifikan antara variabel pelatihan kerja terhadap kinerja karyawan.

Hasil yang serupa juga berdasarkan pengujian statistik t. Dalam pengujian statistik t interpretasi pengambilan keputusan menurut Sugiyono (2012:136) adalah jika $t_{\text {hitung }}>t_{\text {tabel }}$ dan signifikansi $<0,05$ maka $\mathrm{H}_{\mathrm{o}}$ ditolak, dan sebaliknya. Pada hasil pengujian statistik $\mathrm{t}$, diperoleh nilai $t_{\text {hitung }}$ sebesar 4,484 dan nilai untuk $t_{\text {tabel }} 1,659$ dengan nilai signifikansi 0,000 . Hal ini memiliki arti bahwa nilai $t_{\text {hitung }}>t_{\text {tabel }}$ yaitu 4,484 $>1,659$. dan untuk nilai signifikansi $0,000<0,005$. Dengan demikian maka $\mathrm{H}_{\mathrm{o}}$ ditolak, artinya ada pengeruh yang signifikan antara variabel pelatihan kerja dan kinerja karyawan.

\section{Kesimpulan}

1. Pelatihan yang diselenggarakan oleh PDAM Tirta Bumi Wibawa Kota Sukabumi sudah berjalan dengan baik. Hal ini dapat dilihat dari jawaban responden yang menunjukan angka sebesar 4,13 dengan standar deviasi 0,554 yang termasuk dalam kategori baik. Dimensi dengan nilai rata-rata tertinggi yaitu dimensi kebutuhan pelatihan.

2. Kinerja karyawan PDAM Tirta Bumi Wibawa Kota Sukabumi sudah baik, dilihat dari persentase hasil jawaban responden sebesar 4,18 dengan standar deviasi 0,432 yang 
termasuk dalam kategori baik. Dimensi dengan nilai rata-rata tertinggi yaitu dimensi ketepatan hasil kerja.

3. Pengaruh pelatihan kerja terhadap kinerja karyawan sebesar $15,7 \%$, yang artinya pelatihan kerja memberikan kontribusi sebesar $15,7 \%$ terhadap faktor-faktor kinerja karyawan, sedangkan sisanya sebesar 84,3\% dipengaruhi oleh faktor-faktor lain yang tidak diteliti oleh penulis. Berdasarkan hasil regresi sederhana dengan konstanta $(\alpha)$ bernilai 43,163 dengan koefesien regresi (b) 0,392 sehingga muncul persamaan regresi sebagai berikut $\mathrm{Y}=43,163+0,392 \mathrm{X}$. Dari persamaan regresi tersebut, dapat diketahui bahwa setiap penambahan satu angka pelatihan dengan koefesien regresi bernilai positif, maka kinerja karyawan akan meningkat sebesar 0,392. Sedangkan apabila pelatihan kerja, sama dengan nol atau tidak ada perubahan, maka nilai kinerja karyawan sebesar 43,163 .

\section{Saran}

1. Pemberian pelatihan kepada karyawan adalah cara yang baik dalam meningkatkan kinerja karyawan. Walaupun hasil keseluruhan menunjukan bahwa pelatihan di PDAM Tirta Bumi Wibawa Kota Sukabumi sudah baik, namun perusahaan harus meningkatkan dan mengoptimalkan lagi pelatihan yang sudah ada terutama dalam hal materi pelatihan harus selalu update agar peserta pelatihan dapat memahami masalah yang terjadi pada kondisi yang sekarang. Perusahaan harus mengetahui materi yang sesuai dengan kebutuhan karyawannya ketika akan memberikan sebuah pelatihan seperti menganalisis isi program yang akan diberikan, mengutamakan karyawan yang sedang membutuhkan pelatihan, mendatangkan pelatih atau trainer yang sudah handal atau meminta pendapat karyawan tentang pelatihan yang sudah diberikan.

2. Kinerja karyawan PDAM Tirta Bumi Wibawa Kota Sukabumi sudah baik, namun perusahaan harus meningkatkan dan mengoptimalkan lagi faktor faktor yang mempengaruhi kinerja karyawan terutama dalam hal pelatihan kerja. Adapun metode pelatihan yang disarankan adalah : presentasi informasi, metode simulasi dan pelatihan On The Job Training (OJT)

3. Pelatihan mempengaruhi kinerja karyawan sebesar $15,7 \%$. Sedangkan $84,3 \%$ kinerja karyawan PDAM Tirta Bumi Wibawa Kota Sukabumi dipengaruhi oleh gaji, lingkungan kerja, budaya organisasi, kepemimpinan dan motivasi.

4. Bagi peneliti selanjutnya menginngat masih ada faktor lain yang berpengaruh terhadap kinerja karyawan sebesar 84,3\%, maka hal itu dapat dijadikan pertimbangan untuk penelitian selanjutnya agar lebih diketahui tentang faktor-faktor penting yang berpengaruh terhadap kinerja karyawan.

\section{Daftar Pustaka}

Arikunto, S. 2010. Prosedur Penelitian : Suatu Pendekatan Praktik. (Edisi Revisi). Jakarta : Rineka Cipta

Dessler, Gary. 2011. Human Resource Management Thiteenth Edition. New Jersey : Pearson Pretice Hall

Hasibuan, Melayu. 2012. Manajemen Sumber Daya Manusia, cetakan keenam belas. Jakarta : PT Bumi Aksara

Handoko, T. Hani. 2012. Manajemen Personalia dan Sumber Daya Manusia. Yogyakarta : BPFE

Kaswan, 2011, Pelatihan dan Pengembangan untuk Meningkatkan Kinerja SDM, Alfabeta, Bandung

Kaswan. 2012. Manajemen Sumber Daya Manusia untuk Keunggulan Bersaing Organisasi. Graha Ilmu, Yogyakarta 
Mangkunegara, Anwar Prabu 2006. Perencanaan dan Pengembangan SDM. Bandung : Refika Aditama

Mangkunegara, Anwar Prabu 2012. Evaluasi Kinerja SDM, cetakan keenam. Bandung : Refika Aditama.

Peraturan Daerah Kota Sukabumi Nomor 3 Tahun 2009

Roziqin, Muhammad Zainur. 2010. Kepuasaan Kerja. Malang : Averros Press

Sumarsono, HM. Sonny. 2004, Metode Riset Sumber Daya Manusia, Jember : Graha Ilmu

Siagian, Sondang P, 2010. Manajemen Sumber Daya Manusia. Jakarta : Bumi Aksara

Siagian, Sondang P. 2012. Manajemen Sumber Daya Manusia. Jakarta : Bumi Aksara

Sugiyono, 2012. Memahami Penelitian Kualitatif. Bandung : Alfabeta

Sugiyono, 2013. Metode Penelitian Bisnis. Bandung : Alfabeta

Wardani, Shanti Ike, Sutrisno, dan Rudy Eko Pramono. 2014 Pengaruh Job Insecurity terhadap Turnover Itention Karyawan CV, Putra Makmur Abadi Temanggung Jawa Tengah. Artikel Ilmiah Hasil Penelitian Mahasiswa, Hal. 1 - 7

Wibowo, 2011. Manajemen Perubahan. Jakarta : PT. Raja Grafindo Persada

Yulianti, Eli. 2015, Pengaruh Pelatihan Terhadap Kinerja Karyawan Grand Fatma Hotel Di Tenggarong Kutai Katanegara. E Journal Administrasi Bisnis, Volume 3, Nomor 4.

Zulganef. 2008. Metode Penelitian Sosial dan Bisnis. Edisi Pertama. Yogyakarta : Graha Ilmu

Sidik, Ignas G. Conceptual Framework of Factors Affecting SME Development: Mediating Factors on the Relationship of Entrepreneur Traits and SME Performance. Procedia Economics and Finance, Volume 4, 2012, Pages 373-383

Spiro, Rosann L., Stanton, William J., Rich, Gregory A. 2003. Management of a Sales Force. McGrawHill Irwin, New York.

Sugiyono. 2014. Metode Penelitian Kuantitatif, Kualitatif, dan Kombinasi (Mix Methode). Bandung: Alfa Beta.

Suryana.2006. Kewirausahaan. Jakarta: Salemba Empat.

Suryana.2011. Kewirausahaan. Pedoman Praktis, kiat dan Proses menuju Sukses. Jakarta: Salemba Empat.

Tambunan, Tulus. (2002). Usaha Kecil dan Menengah di Indonesia. Jakarta : Salemba Empat.

Westerman, James W. and Simmons, Bret L.2007. The effects of work environment on the personality-performance relationship: an exploratory study.Journal of Managerial Issues. Jun 22, 2007.pp. 339-97.

Westerman, James W.; Simmons, Bret L. 2007. The effects of work environment on the personality-performance relationship: an exploratory study. Journal of Managerial Issuess. Jun 22, 2007. (c. 339-97) 
